$\begin{array}{cl}\text { Türkiye Tarımsal Araştırmalar Dergisi } & \text { Turk J Agric Res } \\ \text { dergipark.gov.tr/tutad } & \text { 2018,5(1): 72-78 } \\ \text { O TÜTAD } & \text { ISSN: 2148-2306 } \\ \text { e-ISSN: 2528-858X } & \text { doi: 10.19159/tutad.363186 }\end{array}$

\title{
Antalya Sahil Koşullarında Koca Fĭğ (Vicia narbonensis L.) Yetiştiriciliği İçin Uygun Ekim Normunun Belirlenmesi
}

\author{
Yaşar ÖZYİĞIT** \\ Akdeniz Üniversitesi, Korkuteli Meslek Yüksekokulu, Bahçe Tarımı Programı, Korkuteli, Antalya, TÜRKIYE
}

\begin{tabular}{|c|c|}
\hline Geliş Tarihi/Received: 06.12.2017 & Kabul Tarihi/Accepted: 09.02.2018 \\
\hline \multicolumn{2}{|l|}{$\overline{\text { ORCID IID }}$} \\
\hline (DD orcid.org/0000-0002-5208-4846 & \\
\hline
\end{tabular}

Özet: Bu çalışma, Antalya sahil koşullarında koca fiğ (Vicia narbonensis L.) bitkisi için en uygun ekim normunu belirlemek amacıyla 2014-2015 ve 2015-2016 yıllarında yürütülmüştür. Deneme, tesadüf blokları deneme desenine göre 3 tekerrürlü olarak kurulmuş ve parsellere 5 farklı ekim normu $\left(5,10,15,20\right.$ ve $\left.25 \mathrm{~kg} \mathrm{da}^{-1}\right)$ uygulanmıştır. Araştırmada bitki boyu, bakla sayısı, baklada tane sayısı, dal sayısı, bakla uzunluğu, 1000 tane ağırlığı, tane verimi, biyolojik verim, kes verimi ve hasat indeksi gibi bazı agronomik veriler incelenmiștir. Çalıșma sonuçları, ekim normlarının incelenen bütün özellikler üzerine istatistiki olarak önemli etkilerinin olduğunu göstermiştir. Ekim normları artıkça bitki boyu, biyolojik verim ve kes verimi değerlerinin arttığı, bakla sayısı, bakla uzunluğu, dal sayısı, baklada tane sayısı, 1000 tane ağırlı̆̆ ve hasat indeksi değerlerinin ise azaldığı tespit edilmiştir. Dane verimi ise $15 \mathrm{~kg} \mathrm{da}^{-1}$ uygulamasında en yüksek değerine ulaşmış, daha yüksek tohum uygulamalarında bir düşüş gözlenmiștir. Elde edilen sonuçlar değerlendirildiğinde, Antalya sahil koşullarında koca fị̆g yetiştiriciliği için en uygun ekim normunun en yüksek tane veriminin alındığı $15 \mathrm{~kg} \mathrm{da}^{-1}$ olduğu ve bu değerden daha fazla veya daha az uygulanacak ekim normlarının verimde düşmeye neden olduğu sonucuna varılmıştır.

Anahtar Kelimeler: Yem bitkisi, koca fiğ, ekim normu, verim

\section{Determination of Optimum Sowing Rate for Narbon Vetch (Vicia narbonensis L.) Cultivation in Antalya Coastal Conditions}

\begin{abstract}
This research was conducted to determine optimum sowing rate for narbon vetch (Vicia narbonensis L.) in Antalya coastal conditions in 2014-2015 and 2015-2016 years. The research was designed according to randomized complete block design with three replicates, and five different sowing rates $\left(5,10,15,20\right.$ and $\left.25 \mathrm{~kg} \mathrm{da}^{-1}\right)$ were performed to parcels. Some agronomic data such as plant height, number of pods, number of seeds per pod, number of branches, pod length, 1000 grain weight, grain yield, biological yield, straw yield, and harvest index were investigated. Study results showed that sowing rates had statistically significant effects on all studied traits. Plant height, seed yield, biological yield and straw yield increased with increasing sowing rate, while pod number, the number of seeds per pod, number of branches, pod length, 1000 seed weight and harvest index decreased. Grain yield reached its highest value at $15 \mathrm{~kg} \mathrm{da}^{-1}$ application and a decrease in higher seed applications were observed. When the results obtained were evaluated, it was concluded that the most appropriate sowing rate for narbon vetch cultivation in Antalya coastal conditions was $15 \mathrm{~kg} \mathrm{da}^{-1}$ where the highest grain yield was achieved and the sowing rates above or below this value resulted in decreased yield.
\end{abstract}

Keywords: Forage crop, narbon vetch, sowing rate, yield 


\section{Giriş}

Hayvansal üretimin en önemli girdilerinden biri olan yem bitkileri, kaba yem kaynağı olması yanında (Ağırbaş ve ark., 2017); toprağın fiziksel ve kimyasal yapısını düzeltmesi ve toprak erozyonun önlenmesi (Yolcu ve Tan, 2008; Özyazıcı ve Özdemir, 2013), kendisinden sonra yetiştirilen bitkilere uygun bir alan bırakması (Kuşvuran ve ark., 2011), yetiştirildiği alanlara fazla miktarda organik madde sağlaması (Çeçen ve ark., 2005) gibi daha birçok faydası bulunmaktadır.

Hayvan beslemede çok büyük bir öneme sahip olmasına rağmen, ülkemizde yem bitkileri yetiştiriciliğine gereken önem verilmemiştir. Tarımı ilerlemiş ülkelerde tarımsal alanlar içinde yem bitkileri ekim alanlarının oranı yaklaşık olarak \% 20-30 civarındadır (Aksu ve Dellal, 2016). Türkiye'de ise bu oran 1990 yılında \% 3.89 iken desteklemelerle, 2016 yılı verilerine göre ancak \% 11'lere kadar çıkartılabilmiştir (Anonim, 2018). Son yıllarda Türkiye'de, hem nüfus artışı hem de insanların satın alma gücündeki artışlar hayvansal ürünlere talebi artırmıştır. Artan bu talebi karşılamak için kültür ırkları veya bu ırkların melezlerinden meydana gelen hayvanlar ile oluşturulan entansif ve yarı entansif işletmelerde de artış olmuştur. Ancak bu işletmeler genelde ahırda yetiştiricilik yaptıkları için kaba yeme olan ihtiyaç artmıştır (Ağırbaş ve ark., 2017). Bu nedenle Türkiye'de kaba yem üretiminin artırılması oldukça önem arz etmektedir.

Kaliteli kaba yem üretimin artırılması, ülkemizde hayvansal üretimin artırabilmesinde en önemli yöntemlerden birisidir (Uzun ve ark., 2008) ve mevcut üretim sisteminde tek y1llık baklagil yem bitkilerinin ekim nöbetine dahil edilmesi kaba yem ihtiyacının karşılanmasına oldukça büyük katkı sağlamaktadır (Özyazıcı ve Manga, 2000; Seydoşoğlu ve ark., 2014). Tek yıllık yem bitkilerinde en önemli gruplardan birisi fiğ türleri (Vicia sp.)'dir. Dünya üzerinde yaklaşık olarak 140150 adet türü olduğu belirtilen fiğler protein, mineral maddeler ve vitaminler bakımından zengin olup, yem değeri oldukça yüksek yem bitkileridir (Avcioğlu ve ark., 2009a). Fiğ türleri içerisinde ise koca fiğ (Vicia narbonensis L.) hayvan besleme açısından önemli bir yere sahiptir. Hem kurağa hem de soğuğa oldukça dayanıklı olan bu bitkinin yeşil kısımları farklı amaçlarla (örneğin, yem ve yeşil gübre bitkisi) kullanılabilmektedir (El-Bok ve ark., 2017). Koca fiğ bitkisinin gövdesi odunsu yapıda olduğu için yatmaya karşı en dayanıklı fiğ türüdür (İptaş ve Yılmaz, 1999) ve bu nedenle karışımlara gerek kalmadan tek başına yetiştirilme olanağı vardır. Ancak, Türkiye'nin birçok yerinde doğal olarak yetişebilen ve tarımı yapılan koca fiğin, sapları ve yaprakları diğer fiğ türleri ile kıyaslandığında lezzetsizdir ve hayvanlar tarafindan fazla tercih edilmezler. Buna karşın, dik olarak gelişmesi ve yatmaya karşı dayanıklı olması nedeniyle tohumluk üretiminin kolaylıkla yapılabilmesi koca fiğ bitkisini önemli bir tane yem bitkisi yapmaktadır. Zira, Avcıŏlu ve ark. (2009b), koca fiğ bitkisinden tane verimi açısından diğer bitki gruplarına nazaran daha yüksek bir verim (535 kg da $\mathrm{da}^{-1}$ elde edildiğini bildirmektedirler. Ayrıca, koca fiğ bitkisinin taneleri protein bakımından oldukça zengindir. Canbolat ve Bayram (2007), koca fiğ tanesindeki protein oranının \% 24 olduğu açıklarken, Larbi ve ark. (2010) bu oranı \% 31.8 olarak belirlemişlerdir.

Bitkisel üretimde verimliliği etkileyen en önemli faktörlerden birisi yetiştiricilik yapılacak alanda toprağın besleyebileceği bitki sayısıdır. Clements ve ark. (1929)'na göre aynı anda aynı kaynağa ihtiyaç duyan bitkiler arasındaki rekabeti, yetiştirilen bitkilerin sıklığı ve rekabet edilen kaynakların durumu etkilemektedir. $\mathrm{Bu}$ nedenle ekimde kullanılacak tohumluk miktarının doğru bir şekilde seçilmesi oldukça büyük bir öneme sahiptir. Birim alana atılacak tohum miktarının uygun bir şekilde ayarlanması gereğinden fazla bitki oluşumunu engelleyerek bitkiler arası rekabetin düzenlenmesini sağlamakta (Tan ve Çomaklı, 2009) ve 1şık, su ve bitki besin elementi rekabetinin olumsuz etkisini ortadan kaldırmaktadır (Katar ve Katar, 2017). Ayrıca optimum tohum miktarının uygulanmasıyla gereksiz tohum kullanımının önüne geçilip, tohum maliyeti de azaltılabilmektedir. Örneğin, yoncada yapılan bir çalışmada $1 \mathrm{~kg}$ üzerinde tohum kullanılmasının verimde önemli bir artış sağlamadığı belirlenmiştir (Tan ve Çomaklı, 2009). Aynı şekilde, Albayrak ve ark. (2011) macar fiğinde dekara $8 \mathrm{~kg}$ 'dan fazla tohum atılması durumunda tane veriminin azaldığını tespit etmişlerdir.

Bitkisel üretimde değişik ekolojik şartlarda her bitki için kullanılacak tohumluk miktarları farklıdır. Bunu belirlemede en uygun yöntem, her tür için değişik iklim ve toprak koşullarında araştırmalar yapmaktır (Tan ve Çomaklı, 2009). Bu konuda farklı bitkilerde [italyan çimi (Altın ve ark., 1994), çemen (Kızıl ve Arslan, 2003), tritikale (Atak ve ark., 2006), buğday (Süzer ve Demir, 2012), aspir (Köse ve Bilir, 2017)] birçok çalışma yürütülmüştür. Ancak, koca fiğ bitkisinin Akdeniz Bölgesi ve özellikle Antalya sahil bandında yetiştiriciliği ile ilgili yeterince bilgi bulunmamaktadır. Bu çalışmada, Antalya sahil ekolojik koşullarında koca fĭğ bitkisinde en uygun ekim normunun belirlenmesi amaçlanmıştır. 


\section{Materyal ve Yöntem}

Araştırma; 2014-2016 yılları arasında, Akdeniz Üniversitesi, Ziraat Fakültesi, Tarla Bitkileri Bölümü, Araştırma ve Uygulama Arazisi'nde yürütülmüştür. Çalışmada bitkisel materyal olarak, Geçit Kuşağı Tarımsal Araştırma Enstitüsü Müdürlüğü (Eskişehir) tarafından geliştirilen Balkan koca fiğ çeşidi kullanılmıştır.

Araştırma alanı toprağına ait bazı fiziksel ve kimyasal özellikler Tablo 1'de verilmiştir. Tabloda görüldüğü gibi araştırma alanı toprağı; killi bünyeli, hafif tuzlu, kireç oranı yüksek, kuvvetli alkalin karakterli olup, organik madde içeriği düşük, alınabilir fosfor içeriği yeterli ve potasyum içeriği çok yüksek düzeydedir (Tablo 1).

Tablo 1. Araştırma yeri topraklarının bazı fiziksel ve kimyasal özellikleri

\begin{tabular}{lc}
\hline Toprak özelliği & Değer \\
\hline Kil, \% & 51 \\
Silt, \% & 34 \\
Kum, \% & 15 \\
EC, ds m ${ }^{-1}$ & 2.5 \\
Kireç, \% & 28.3 \\
pH & 8.7 \\
Organik madde, \% & 1.9 \\
Alınabilir fosfor, ppm & 139 \\
Alınabilir potasyum, ppm & 327 \\
\hline
\end{tabular}

Çalışmanın yürütüldüğü yıllara (2014-2015 ve 2015-2016) ve uzun yıllar ortalamasina ait; toplam yağış, ortalama sıcaklık ve ortalama oransal nem değerlerine ait veriler Şekil 1'de gösterilmiştir. Şekil 1 incelendiğinde; yıllar arasında sıcaklık ve nem değerleri arasında fazla bir fark görülmezken, denemenin ikinci yılında birinci yıla göre oldukça düşük bir yağış düştüğü görülmektedir. Denemenin yürütüldüğü dönemlere ait iklim verileri uzun yıllar ortalamaları ile kıyaslandığında ise, hem yağış hem de oransal nem bakımından 1. y1l yüksek, 2. yıl ise düşük değerler kaydedilmişken, ortalama sıcaklık bakımından her iki deneme yılında da uzun yıllar ortalamasına göre daha yüksek değerler görülmüştür (Şekil 1).

Araştırmada denemeler; tesadüf bloklar deneme desenine göre 3 tekrarlamalı olarak kurulmuş olup, her bir parsel $\left(4.2 \mathrm{~m}^{2}\right) 2$ metre uzunluğunda ve 8 sıradan oluşmuştur. Sıra arası mesafe $30 \mathrm{~cm}$ olarak ayarlanmış, parsel ve blok aralarında ise $1.5 \mathrm{~m}$ boşluk bırakılmıştır. Birinci yıl ekimleri 22 Kasım 2014, ikinci yıl ekimleri ise 25 Kasım 2015 tarihinde yapılmıştır. Araştırmada faktör konusu olarak ele alınan ekim normu; 5, 10, 15,20 ve $25 \mathrm{~kg} \mathrm{da}^{-1}$ tohum olarak uygulanmıştır. Denemelerde ekimle birlikte, her parsele homojen olarak $4 \mathrm{~kg} \mathrm{da}^{-1}$ azot ve $7 \mathrm{~kg} \mathrm{da}{ }^{-1} \mathrm{P}_{2} \mathrm{O}_{5}$ gelecek şekilde diamonyum fosfat (DAP) gübresi uygulanmıştır.
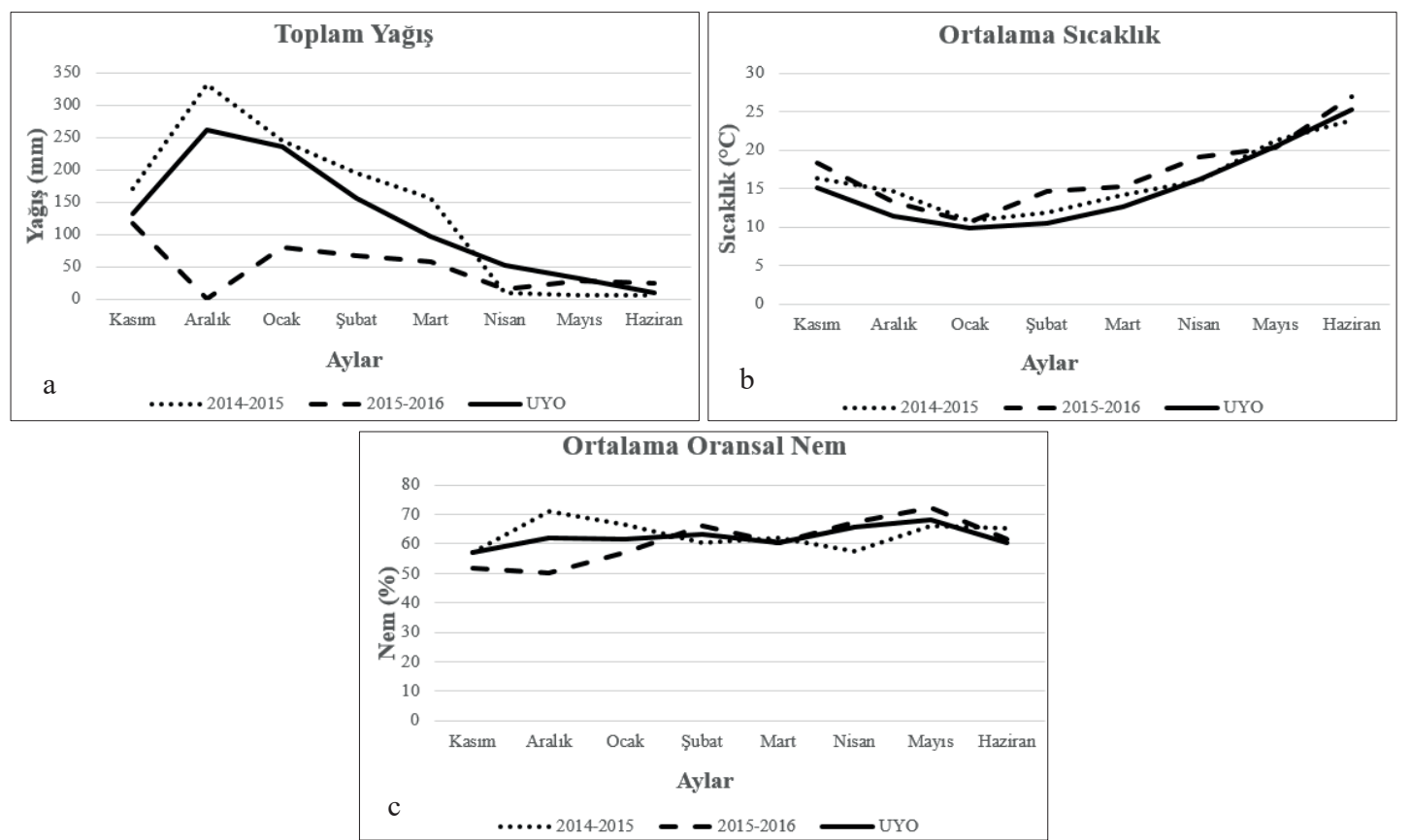

Şekil 1. Çalışmanın yürütüldüğü dönemlere (2014-2015, 2015-2016) ve uzun yıllar (1929-2016) ortalamasına ait Antalya ili iklim verileri [Toplam yağış (a), Ortalama sıcaklık (b), Ortalama oransal nem (c)]*

*: Veriler, Antalya Meteoroloji İstasyonu'ndan alınmıştır. 
Hasat işlemleri her iki yılda, baklaların tamamen olgunlaştığ (Avcıŏlu ve ark., 2009b), Haziran ayının başlarında yapılmıştır. Hasat sırasında her parselin kenarlarından birer sıra ve her sıranın başlarından $25 \mathrm{~cm}$ kenar tesiri olarak atılmıştır. Araştırmada; bitki boyu (cm), bitkide bakla sayısı (adet), bakla uzunluğu (cm), dal sayısı (adet), baklada tane sayısı (adet), tane verimi $\left(\mathrm{kg} \mathrm{da}^{-1}\right), 1000$ tane ağırlığ 1 (g), biyolojik verim $\left(\mathrm{kg} \mathrm{da}^{-1}\right)$, kes verimi $\left(\mathrm{kg} \mathrm{da}^{-1}\right)$ ve hasat indeksi (\%) gibi agronomik veriler belirlemiştir.

Araştırmadan elde edilen verilere; SAS paket programında, tesadüf blokları deneme desenine göre varyans analizi uygulanmış ve önemli çıkan faktör ortalamalarına Duncan çoklu karşılaştırma testi uygulanarak ortalamalar arasındaki farklar incelemiştir.

\section{Bulgular ve Tartışma}

\subsection{Bitki boyu}

Araştırmada ölçülen bitki boyuna ilişkin iki y1llık ortalama sonuçlar Tablo 2'de sunulmuştur. Tablo 2'den de görüldüğü gibi, denemede bitki boyu bakımından elde edilen iki yıllık ortalama değerler arasındaki farklar istatistiksel olarak çok önemli $(p<0.01)$ bulunmuştur. En düşük bitki boyu $73 \mathrm{~cm}$ ile en düşük bitki sıklığı olan $5 \mathrm{~kg} \mathrm{da}^{-1}$ uygulamasında belirlenirken, diğer uygulamalar istatistiki olarak aynı grupta yer almış ve $81-89 \mathrm{~cm}$ arasında değişen bitki boyları ile en yüksek değerleri vermiştir (Tablo 2). Bu durum tarımsal üretimde bitki boylarının bitki sıklığından etkilendiğini göstermektedir. Bitkilerde boy, esas olarak genetik faktörler tarafından belirlense de, çevre faktörlerinin de bitki boyu üzerine oldukça büyük etkisi vardır (Katar ve Katar, 2016). Bu çevre faktörlerinin en önemlilerinden birisi 1şıktır. Sik dikimlerde bitkiler 1şık almakta zorlandıklarından, 1şığa ulaşabilmek için boyları uzamaktadır. Bu durum koca fiğ (Anlarsal, 1996), kişniş (Katar ve Katar, 2016), sakız fasulyesi (Cebeci ve ark., 2016) ve mısır (Taş ve ark., 2016) gibi daha birçok bitkide de yapılan çalışmalarda da belirlenmiştir.

\subsection{Bitkide bakla sayısı, bakla uzunluğu ve dal sayısı}

Bakla sayısı, bakla uzunluğu ve dal sayısına ait verilere uygulanan istatistik analizler sonucunda; iki yıllık ortalama bakla sayısı değerleri arasındaki farklar $\mathrm{p}<0.05$ düzeyinde önemli bulunurken, bakla uzunluğu ve dal sayısı değerleri arasındaki farkların p $<0.01$ düzeyinde istatistiki olarak önemli olduğu belirlenmiştir. Bitki sıklığı artıkça her üç özelliğe ait değerlerde düşüş gözlenmiştir. Bakla sayısı, bakla uzunluğu ve dal sayısı için en yüksek değerler sirasiyla 14 adet, $6.23 \mathrm{~cm}$ ve 4 adet ile $5 \mathrm{~kg} \mathrm{da}^{-1}$ uygulamasından elde edilirken; en düşük değerler yine sirasiyla 8 adet, $5.36 \mathrm{~cm}$ ve 2 adet ile 25 $\mathrm{kg} \mathrm{da}^{-1}$ ekim normu uygulamasında belirlenmiştir (Tablo 2). Bitkisel üretimde bitki sıklığı arttıkça, 1şık ve havadan daha fazla yararlanmak isteyen bitkiler arasında oluşan rekabet sonucunda, bitkiler dallanmayı azaltmaktadır. Dallanması azalan ve cılız gelişen bitkilerde ise bakla sayısının azalması beklenen bir durumdur (Toğay ve ark., 2006).

\subsection{Baklada tane sayısı}

Tablo 2 incelendiğinde, baklada tane sayısı değerleri arasındaki farkların istatistiki olarak $\mathrm{p}<0.01$ düzeyinde önemli olduğu görülmektedir. En yüksek değer, 5 adet ile en düşük bitki sıklığ1 (5 kg $\mathrm{da}^{-1}$ ) uygulamasından elde edilirken; bitki sıklığ 1 artıkça tane sayısı düşmüş ve en düşük değer 4 adet ile $25 \mathrm{~kg} \mathrm{da}^{-1}$ uygulamasında belirlenmiştir. Ancak baklada tane sayısı değerleri arasında istatistiki olarak bir farklılık olsa da, sonuçlar incelendiğinde en yüksek ve en düşük değerler arasındaki farkın sadece 1 olduğu ve arada çok büyük farkların olmadığı görülmektedir. Toğay ve ark. (2006) baklada tane sayısının genellikle çeşide özgü bir karakter olduğunu ve bitki sıklıklarından çok fazla etkilenmediğini bildirmektedirler.

\subsection{Tane verimi}

Araştırmada elde edilen sonuçlar incelendiğinde, farklı ekim normların tane verimi üzerine etkisinin istatistiki olarak $\mathrm{p}<0.01$ düzeyinde önemli olduğu bulunmuştur. En yüksek tane verimi $293 \mathrm{~kg} \mathrm{da}^{-1}$ ile $15 \mathrm{~kg} \mathrm{da}^{-1}$ ekim normunda

Tablo 2. Denemede incelenen özelliklere ilişkin iki yıllık (2014-2015 ve 2015-2016) ortalamalar $^{1}$

\begin{tabular}{|c|c|c|c|c|c|c|c|c|c|c|}
\hline $\begin{array}{c}\text { Ekim } \\
\text { normu } \\
\left(\mathrm{kg} \mathrm{da}^{-1}\right)\end{array}$ & $\begin{array}{l}\text { Bitki } \\
\text { boyu } \\
(\mathrm{cm})\end{array}$ & $\begin{array}{c}\text { Bitkide } \\
\text { bakla } \\
\text { say1sı } \\
\text { (adet) }\end{array}$ & $\begin{array}{l}\text { Bakla } \\
\text { uzunluğu } \\
\quad(\mathrm{cm})\end{array}$ & $\begin{array}{c}\text { Dal } \\
\text { say1s1 } \\
\text { (adet) }\end{array}$ & $\begin{array}{c}\text { Baklada } \\
\text { tane } \\
\text { say1s1 } \\
\text { (adet) }\end{array}$ & $\begin{array}{c}\text { Tane } \\
\text { verimi } \\
\left(\mathrm{kg} \mathrm{da}^{-1}\right)\end{array}$ & $\begin{array}{c}1000 \\
\text { tane } \\
\text { ağırliğ1 } \\
(\mathrm{g})\end{array}$ & $\begin{array}{l}\text { Biyolojik } \\
\text { verim } \\
\left(\mathrm{kg} \mathrm{da}^{-1}\right)\end{array}$ & $\begin{array}{c}\text { Kes } \\
\text { verimi } \\
\left(\mathrm{kg} \mathrm{da}^{-1}\right)\end{array}$ & $\begin{array}{c}\text { Hasat } \\
\text { indeksi } \\
(\%)\end{array}$ \\
\hline 5 & $73 \mathrm{~b}$ & $14 \mathrm{a}$ & $6.23 \mathrm{a}$ & $4 a$ & $5 a$ & $115 \mathrm{e}$ & $266 a$ & $359 \mathrm{~d}$ & $245 \mathrm{~d}$ & $32 \mathrm{a}$ \\
\hline 10 & $81 \mathrm{a}$ & $13 \mathrm{a}$ & $5.88 \mathrm{~b}$ & $3 \mathrm{~b}$ & $5 \mathrm{ab}$ & $184 \mathrm{~d}$ & $245 \mathrm{~b}$ & $554 \mathrm{c}$ & $370 \mathrm{c}$ & $33 \mathrm{a}$ \\
\hline 15 & $83 a$ & $11 \mathrm{~b}$ & $5.70 \mathrm{bc}$ & $3 \mathrm{bc}$ & $4 \mathrm{bc}$ & 293 a & $235 \mathrm{bc}$ & $927 \mathrm{~b}$ & $634 b$ & $32 \mathrm{a}$ \\
\hline 20 & $89 \mathrm{a}$ & $9 \mathrm{c}$ & $5.63 \mathrm{c}$ & $2 \mathrm{~cd}$ & $4 \mathrm{bc}$ & $223 \mathrm{~b}$ & $231 \mathrm{c}$ & $1026 \mathrm{a}$ & $802 \mathrm{a}$ & $22 b$ \\
\hline 25 & $88 \mathrm{a}$ & $8 \mathrm{c}$ & $5.36 \mathrm{~d}$ & $2 d$ & $4 \mathrm{c}$ & $208 \mathrm{c}$ & $233 \mathrm{c}$ & $1020 \mathrm{a}$ & $812 \mathrm{a}$ & $20 \mathrm{~b}$ \\
\hline F değeri & $6.28^{* *}$ & $24.69^{*}$ & $17.43^{* *}$ & $20.78^{* *}$ & $4.58^{* *}$ & $1205.20^{* *}$ & $14.74^{*}$ & $448.60^{* *}$ & $300.89^{* *}$ & $161.42^{* *}$ \\
\hline
\end{tabular}

${ }^{1}$ : Aynı sütunda farklı harflerle gösterilen ortalamalar arasındaki farklar istatistiki olarak önemlidir $\left({ }^{*}: \mathrm{p}<0.05,{ }^{* *}: \mathrm{p}<0.01\right)$ 
belirlenirken, $5 \mathrm{~kg} \mathrm{da}^{-1}$ ekim normunda $115 \mathrm{~kg} \mathrm{da}^{-1}$ ile en düşük tane verimi tespit edilmiştir. Çalışmada, $15 \mathrm{~kg} \mathrm{da}^{-1}$ uygulamasından daha yüksek ekim normlarında ise tane verimi değerleri azalmıştır (Tablo 2). Tarımsal üretimde birim alandaki bitki yoğunluğunun fazla olması metrekaredeki fertil çiçek sayısını artırmakta (Kaydan ve ark., 2011) ve daha fazla tane verimi elde edilmesini sağlamaktadır. Ancak bitki yoğunluğunun optimumdan fazla olması durumunda, bitki başına düşen yaşam alanı azalmakta ve bitkiler arası rekabetin artması nedeniyle kardeşlenmede azalmalar meydana gelmektedir (Atak ve Çiftçi, 2005). Bu durum da verimlerde düşüşlere neden olmaktadır. Çalışmadan elde ettiğimiz bulgular bu yöndedir ve bulgularımız Çakmak (2002) tarafından koca fiğgde ve Albayrak ve ark. (2011) tarafından macar fiğinde yapılan çalışmaların sonuçlarıyla uyum göstermektedir. Diğer bazı çalışmalarda ise; Türk (1999) ve Türk ve ark. (2003) koca fiğde, Karayel ve ark. (2016) baklada ve Abrak ve Y1lmaz (2017) susamda birim alandaki bitki sayısı artıkça tane veriminin arttığını belirlemişlerdir.

\subsection{0 tane ağırlığı}

Çalışmadan elde edilen bulgular, ekim normlarının 1000 tane ağırlığı üzerine etkisinin $\mathrm{p}<0.05$ düzeyinde istatistiki olarak önemli olduğunu göstermektedir. Tablo 2 incelendiğinde, ekim normları artıkça 1000 tane ağırlığı değerlerinin azaldığı görülmektedir. En yüksek 1000 tane ağırlı̆̆ $266 \mathrm{~g}$ ile $5 \mathrm{~kg} \mathrm{da}^{-1}$ uygulamasında tespit edilirken, en düşük değerler $231 \mathrm{~g}$ ile $20 \mathrm{~kg}$ $\mathrm{da}^{-1}$ ve $233 \mathrm{~g}$ ile $25 \mathrm{~kg} \mathrm{da}^{-1}$ uygulamasindan elde edilmiştir (Tablo 2). Bulgularımız Yılmaz (2008)' in bildirdiği sonuçlarla benzerlik göstermektedir. Tarımsal üretimde ekim normu dolayısıyla bitki sıklığı arttıkça birim alandaki bitki sayısı artmaktadır. Artan bitki sayıları da bitkiler arası rekabeti artmakta ve tanelerin daha ufak ve cilız oluşmasına ve bin tane ağırlığının düşmesine neden olmaktadır (Kaydan ve ark., 2011). Bu durum farklı bitkilerde yapılan birçok çalışmada da rapor edilmiştir (Karasu, 1999; Uzun ve ark., 2004; Albayrak ve ark., 2011; Süzer ve Demir, 2012).

\subsection{Biyolojik verim ve kes verimi}

Biyolojik verim ve kes verimi değerleri incelendiğinde ekim normu uygulamalarının bu özellikler üzerine etkisinin istatistiki olarak $p<0.01$ düzeyinde önemli olduğu görülmüştür. Ekim normu dolayısıyla bitki sıklığı artışına paralel olarak her iki özellikte de artışlar tespit edilmiştir. En yüksek biyolojik verim değerleri istatistiki olarak aynı grupta yer alan $20 \mathrm{~kg} \mathrm{da}^{-1}\left(1026 \mathrm{~kg} \mathrm{da}^{-1}\right)$ ve $25 \mathrm{~kg}$ $\mathrm{da}^{-1}\left(1020 \mathrm{~kg} \mathrm{da}^{-1}\right)$ ekim normu uygulamalarında belirlenirken; en düşük ekim normu olan $5 \mathrm{~kg} \mathrm{da}^{-1}$ uygulamasında ise biyolojik verim değeri $359 \mathrm{~kg}$ $\mathrm{da}^{-1}$ ile en düşük değeri vermiştir. Kes verimi değerlerinde de benzer bir durum ortaya çıkmış ve en yüksek ekim normu değeri olan 25 ve $20 \mathrm{~kg} \mathrm{da}^{-1}$ uygulamalarında sirasıyla, $812 \mathrm{~kg} \mathrm{da}^{-1}$ ve 802 $\mathrm{kg} \mathrm{da}^{-1}$ ile en yüksek kes verimi alınmıştır. En düşük kes verimi ise $245 \mathrm{~kg} \mathrm{da}^{-1}$ ile $5 \mathrm{~kg} \mathrm{da}^{-1}$ uygulamasından elde edilmiştir (Tablo 2). Bitki sıklığının arttığı durumlarda bitki başına düşen hem vejetatif hem de generatif aksam ağırlıkları azalmaktadır. Ancak birim alandaki bitki sayısı arttığ1 için tohum, yaprak ve sap gibi toprak üstü organlarının toplam ağırlığında artış görülmekte ve bu durum hem biyolojik verimi hem de kes verimini artırmaktadır. Yilmaz (2008) koca fiğde ve Albayrak ve ark. (2011) macar fiğinde benzer sonuçlar elde etmişler ve bitki yoğunluğu artıkça biyolojik verimin arttığını bildirmişlerdir.

\subsection{Hasat indeksi}

Bitkiden elde edilen tohum miktarının biyolojik verime bölünmesi ve çıkan sonucun 100 ile çarpılmasıyla elde edilen hasat indeksi (Anonim, 2001) değerleri incelendiğinde, ekim normlarının hasat indeksi üzerine istatistiki anlamda $\mathrm{p}<0.01$ düzeyinde önemli bir etkisi olduğu görülmüştür. Çalışmada düşük bitki yoğunluklarında yüksek hasat indeksi değerleri tespit edilmiştir. Buna göre, en yüksek hasat indeksleri \% 33 ile $10 \mathrm{~kg} \mathrm{da}^{-1}$ ve $\% 32$ ile 5 ve $15 \mathrm{~kg} \mathrm{da}^{-1}$ uygulamalarında elde edilirken; en düşük değerler, \% 20 ile $25 \mathrm{~kg} \mathrm{da}^{-1}$ uygulamasinda ve $\% \quad 22$ ile $20 \quad \begin{array}{llll} & \mathrm{kg} & \mathrm{da}^{-1}\end{array}$ uygulamasında belirlenmiştir (Tablo 2). Çalışmamızda elde ettiğimiz bulgulara benzer sonuçlar Gezahegn ve Tesfaye (2017) tarafindan koca fiğ bitkisine morfolojik olarak benzeyen bakla bitkisinde elde edilmiş, araştırıcılar bitki yoğunluğu artıkça hasat indeksinin düştüğünü ve bu duruma bitki sıklığının artmasıyla karbonhidrat alımının azalmasının neden olduğunu bildirmişlerdir. Kaydan ve ark. ( 2011), ise buğdayda yaptıkları çalışmada bitki sıklığı arttıkça, birim alandaki sap sayısının fazla olması nedeniyle hasat indeksinin düştüğünü belirtmişlerdir.

\section{Sonuçlar}

Antalya sahil koşullarında koca fiğ bitkisi için uygun ekim normunu belirlemek amacıyla yürütülen bu çalışmanın sonuçlarına göre; dekara atılacak tohumluk miktarı artıkça bitki boyu değerlerinin arttığı buna karşılık; bakla sayısı, bakla uzunluğu, dal sayısı ve baklada tane sayısı değerlerin azaldığ 1 görülmüştür. Ekim normu dolayısıyla bitki sıklığı artıkça verimle ilişkili özelliklerden 1000 tane ağırlığı azalmış, biyolojik verim ve kes verimi ise artmıştır. Tane verimi ise 15 
$\mathrm{kg} \mathrm{da}^{-1}$ uygulamasında maksimum düzeyine ulaşmıştır. Hasat indeksi düşük ekim normlarında yüksek değerler verirken, yüksek ekim normlarında azalmıştır. Çalışmanın sonuçları toplu olarak değerlendirildiğinde, Antalya sahil koşullarında koca fiğ yetiștiriciliği için en uygun ekim normunun özellikle en yüksek tane veriminin alındığı 15 $\mathrm{kg} \mathrm{da}^{-1}$ olduğu görülmüş ve bu değerden daha düşük veya daha yüksek uygulanacak tohum miktarlarında verimin düşeceği sonucuna varılmıştır.

\section{Kaynaklar}

Abrak, S., Y1lmaz, A., 2017. Yarı kurak iklim koşullarında farklı ekim zamanı ve bitki sıklıklarının ikinci ürün susam (Sesamum indicum L.)' da verim ve bazı parametreler üzerine etkilerinin belirlenmesi. Türkiye Tarımsal Araştırmalar Dergisi, 4(3): 232240.

Ağırbaş, N.C., Sapmaz, K., Koç, A., 2017. Eskişehir ilinde yem bitkileri ekiliş alanı ve üretim miktarı üzerine tarımsal desteklemelerin etkisi. Atatürk Üniversitesi Ziraat Fakültesi Dergisi, 48(1): 65-72.

Aksu, N., Dellal, İ., 2016. Afyonkarahisar ilinde yem bitkileri desteğinin büyükbaş hayvancılık faaliyetleri ile ilişkisinin değerlendirmesi. Yüzüncü Yll Üniversitesi Tarım Bilimleri Dergisi, 26(1): 52-60.

Albayrak, S., Türk M., Yüksel, O., 2011. Effect of row spacing and seeding rate on Hungarian vetch yield and quality. Turkish Journal of Field Crops, 16(1): 54-58.

Altın, M., Orak, A., Tuna, M., 1994. Farklı ekim normu ve sıra arası mesafenin İtalyan çiminin (Lolium multiflorum Lam.) önemli bazı verim ve verim unsurlar1 üzerine etkisi. Tekirda $\breve{g}$ Ziraat Fakültesi Dergisi, 3(1-2): 183-187.

Anlarsal, A.E., 1996. The effect of different cutting stages and seeding rates on forage and seed yields of narbonne vetch (Vicia narbonensis L.). Turkish Journal of Agriculture and Forestry, 20: 529-534.

Anonim, 2001. Tarımsal Değerleri Ölçme Denemeleri Teknik Talimat. Fiğ türleri (Vicia L. species). T.C. Tarım ve Köyişleri Bakanlığı Tohumluk Tescil ve Sertifikasyon Merkezi Müdürlüğü, Ankara.

Anonim, 2018. T.C. Gıda Tarım ve Hayvancılık Bakanlığ1, Bitkisel Üretim Genel Müdürlüğü Faaliyetleri, Mart 2017. (http://www.tarim.gov.tr/sgb/Belgeler/SagMenuVeri ler/BUGEM. pdf), (Erişim tarihi: 07.02.2018).

Atak, M., Çiftçi, C.Y., 2005. Tritikalede farklı ekim sıklıklarının verim ve bazı verim öğelerine etkileri. Tarım Bilimleri Dergisi, 11(1): 98-103.

Atak, M., Kaya, M., Çiftçi, C., Ünver, S., 2006. Tohum miktarlarının tritikale (x Triticosecale Wittmack) genotiplerinde verim ve bazı verim öğelerine etkileri. Süleyman Demirel Üniversitesi Fen Bilimleri Enstitüsü Dergisi, 10(1): 40-47.

Avcıoğlu, R., Hatipoğlu, R., Karadağ, Y., 2009a. Fiğler, burçak ve kara mercimek. (Ed: R. Avcioğlu, R. Hatipoğlu, Y. Karadağ), Yembitkileri (Baklagil
Yembitkileri), T.C. Tarım ve Köyişleri Bakanlığı, Tarımsal Üretim ve Geliştirme Genel Müdürlüğü, İzmir, s. 402-434.

Avcioğlu, R., Kavut, Y.T., Okkaoğlu, H., 2009b. Koca fiğ (Vicia narbonensis L.). (Ed: R. Avcioğlu, R. Hatipoğlu, Y. Karadağ), Yembitkileri (Baklagil Yembitkileri), T.C. Tarım ve Köyişleri Bakanlığı, Tarımsal Üretim ve Geliştirme Genel Müdürlüğü, İzmir, s. 421-425.

Canbolat, Ö., Bayram, G., 2007. Bazı baklagil danelerinin in vitro gaz üretim parametreleri, sindirilebilir organik madde ve metabolik enerji içeriklerinin karşılaştırılması. Uludă̆ Üniversitesi Ziraat Fakültesi Dergisi, 21(1): 31-42.

Cebeci, G., Gökkuş, A., Alatürk, F., 2016. Farklı ekim sıklığının sakı fasulyesinde [Cyamopsis tetragonobla (L.) Taub.] ot verimi ve baz1 verim özelliklerine etkisi. Alinteri Zirai Bilimler Dergisi, 30(1): 53-59.

Clements, F.E., Weaver, J.E., Hanson, H.C., 1929. Plant Competition: An Analysis of Community Functions. Carnegie Institution of Washington Publication No. 398, Carnegie Institution of Washington, DC.

Çakmak, M., 2002. Koca fiğ (Vicia narbonensis L.)'de tohumluk miktarının ot ve tane verimine etkisi. Yüksek lisans tezi, Ankara Üniversitesi, Fen Bilimleri Enstitüsü, Ankara.

Çeçen, S., Öten, M., Erdurmuş, C., 2005. Batı Akdeniz sahil kuşağında bazı tek yıllık baklagil yem bitkilerinin ikinci ürün olarak değerlendirilmesi. Akdeniz Üniversitesi Ziraat Fakültesi Dergisi, 18(3): 331-336.

El-Bok, S., Jabri, C., Ben-Brahim, T., Lamine, O., ElGazzah, M., Zoghlami-Khélil, A., 2017. Pod, seed traits and cytotaxonomic studies of some Vicia narbonensis L. accessions (Fabaceae). Saudi Journal of Biological Sciences, 24(7): 1689-1696.

Gezahegn, A.M., Tesfaye, K., 2017. Optimum inter and intra row spacing for faba bean production under Fluvisols. MAYFEB Journal of Agricultural Science, 4: 10-19.

İptaş, S., Yılmaz, M., 1999. Tokat şartlarında yetiştirilen değişik macar fiği+tritikale karışım oranlarının verim ve kaliteye etkileri. ANADOLU (Ege Tarmsal Araştırma Enstitüsü Dergisi), 9(2): 105-113.

Karasu, A., 1999. Nohutta (Cicer arietinum L.) farklı sira aralıklarının bazı tarımsal özellikler üzerine etkisi. Türkiye III. Tarla Bitkileri Kongresi, 15-20 Kasım, Adana, 3: 382-388.

Karayel, R., Topal, N., Bozoğlu, H., 2016. Bakla (Vicia faba L.)'da farklı ekim sıklıklarının yaprak alanı ve verim unsurlarına etkisi. Tarla Bitkileri Merkez Araştırma Enstitüsü Dergisi, 25(Özel say1-1): 213219.

Katar D., Katar, N., 2016. Determination of the effect of plant density on yield and yield components for two different coriander cultivars (Coriandrum sativum L.). Uluslararası Tarım ve Yaban Hayatı Bilimleri Dergisi, 2(1): 33-42.

Katar, D., Katar, N., 2017. Eskişehir ekolojik koşullarında farklı karabuğday (Fagopyrum 
esculentum Moench) çeșidinde uygun ekim normunun belirlenmesi. Tarla Bitkileri Merkez Araştırma Enstitüsü Dergisi, 26(1): 31-39.

Kaydan, D., Tepe, I., Yağmur, M., Yergin, R., 2011. Ekim yöntemi ve sıklığının buğdayda tane verimi, bazı verim öğeleri ve yabancı otlar üzerine etkileri. Tarım Bilimleri Dergisi, 17(4): 310-323.

Kızı1, S., Arslan, N., 2003. Bazı çemen (Trigonella foenum-graecum L.) hatlarında farklı ekim normlarının verim ve verim özellikleri üzerine etkilerinin araştırılması. Tarım Bilimleri Dergisi, 9(4): 395-401.

Köse, A., Bilir, Ö., 2017. Aspir (Carthamus tinctorius L.) bitkisinde sira arası mesafe ve ekim normunun verim ve verim unsurları üzerine etkisi. Tarla Bitkileri Merkez Araştırma Enstitüsü Dergisi, 26(1):45-52

Kuşvuran, A., Nazlı, R.İ., Tans1, V., 2011. Türkiye'de ve Batı Karadeniz Bölgesi'nde çayır-mera alanları, hayvan varlığı ve yem bitkileri tarımının bugünkü durumu. Gaziosmanpașa Üniversitesi Ziraat Fakültesi Dergisi, 28(2): 21-32.

Larbi, A., El-Moneim, A.A., Nakkoul, H., Jammal, B., Hassan, S., 2010. Intra-species variations in yield and quality determinants in Vicia species: 2. Narbon vetch (Vicia narbonensis L.). Animal Feed Science and Technology, 162(1-2): 20-27.

Özyazıcı, M.A., Manga, İ., 2000. Çarşamba Ovası sulu koşullarında yeşil gübre olarak kullanılan bazı baklagil yembitkileri ile bitki artıklarının kendilerini izleyen misır ve ayçiçeğinin verim ve kalitesine etkileri. Türk Tarım ve Ormancılık Dergisi, 24(1): 95103.

Özyazıcı, M.A., Özdemir, N., 2013. Çarşamba Ovası koşullarında yem ve yeşil gübre amacıyla yetiştirilen yem baklası (Vicia faba L.)'nın toprağın bazı fiziksel ve kimyasal özelliklerine etkileri. Adnan Menderes Üniversitesi Ziraat Fakültesi Dergisi, 10(1): 15-23.

Seydoşoğlu, S., Sayar, M.S., Başbağ, M., 2014. Diyarbakır ekolojik koşullarında bazı koca fiğ genotiplerinin verim ve verim unsurları. Türk Tarım ve Doğa Bilimleri Dergisi, 1(1): 64-71.
Süzer, S., Demir, L., 2012. Sirta ekim sisteminde buğdayda (Triticum aestivum L.) en uygun ekim normunun belirlenmesi. Tarım Makinaları Bilimi Dergisi, 8(4): 387-392.

Tan, M., Çomaklı, B., 2009. Yem bitkileri tarımının genel özellikleri. (Ed: R. Avcıŏlu, R. Hatipoğlu, Y. Karadağ), Yembitkileri (Baklagil Yembitkileri), T.C. Tarım ve Köyişleri Bakanlığı, Tarımsal Üretim ve Geliştirme Genel Müdürlügü̆, İzmir, s. 94-112.

Taş, T., Öktem, A.G., Öktem, A., 2016. Harran ovası koşullarında yetiştirilen mısır bitkisinde (Zea mays L. indentata) farklı ekim sıklığının silaj verimi ve bazı tarımsal özelliklere etkisi. Tarla Bitkileri Merkez Araştırma Enstitüsü Dergisi, 25(Özel say1-1): 64-69.

Toğay, N., Toğay, Y., Erman, M., Yıldırım, B., 2006. Kışlık iki bezelye hattı (Pisum sativum ssp. arvense L.)'nda farklı bitki sıklıklarının bazı tarımsal özellikler üzerine etkisi. Yüzüncü Yll Üniversitesi Tarım Bilimleri Dergisi, 16(2): 97-103.

Türk, M.A., 1999. Effect of sowing rate and irrigation on dry biomass and grain yield of bitter vetch (Vicia ervilia) and narbon vetch (Vicia narbonensis). Indian Joumal of Agricultural Sciences, 69(6): 438-443.

Türk, M.A., Abd El Tawaha, R.M., Samara, N., 2003. Effects of seeding rate and date and phosphorus application on growth and yield of narbon vetch (Vicia narbonensis L). Agronomie, 23(4): 1-4.

Uzun, A., Bilgili, U., Sincik, M., Açıkgöz, E., 2004. Effects of seeding rates on yield and yield components of Hungarian vetch (Vicia pannonica Crantz.). Turkish Journal of Agriculture and Forestry, 28(3): 179-182.

Uzun, F., Sulak, M., Uğur, S., 2008. Gazal boynuzu türlerinin ülkemiz için önemi. Türk Bilimsel Derlemeler Dergisi, 1(2): 45-54.

Yılmaz, Ş., 2008. Effects of increased phosphorus rates and plant densities on yield and yield-related traits of narbon vetch lines. Turkish Journal of Agriculture and Forestry, 32(1): 49-56.

Yolcu, H., Tan, M., 2008. Ülkemiz yem bitkileri tarımına genel bir bakış. Tarım Bilimleri Dergisi, 14(3): 303312 . 